DOI: 10.46340/eujem.2020.6.4.10

\title{
Viktoriia Kuzina
}

ORCID ID: http://orcid.org/0000-0002-6944-9194

Kharkiv National Agrarian University named after V.V. Dokuchayev, Ukraine

\section{INVESTMENT AND INNOVATION COMPONENTS OF FORMATION OF THE MALT INDUSTRY IN UKRAINE}

\begin{abstract}
Modern integration processes equalize the conditions of economic activity, eliminate national barriers for economic entities in world markets, have a positive impact on the movement of resources, including investment and openness to innovation.

Thus, it was vital to restore the decayed malt production according to world quality standards and form a strong raw material base in the related agro-industrial sector for the Ukrainian brewing industry, which started operating at the beginning of the new century.

The article explores the role of foreign investments in overcoming the crisis in the malt industry of Ukraine, the experience of efficient use of foreign capital, the peculiarities of investment and innovation activity of world malt corporations Malteurop and Soufflet and domestic "Obolon" on the formation of the modern raw material base of malt production in Ukraine.

Finally, we conclude that such experience of production activities and building partnerships deserves the attention of scientists and practical implementation in complex processing subsectors related to the agro-industrial sector.
\end{abstract}

Keywords: malt, barley, industry, investment, innovation, agricultural enterprise, partner, Malteurop, Soufflet.

Problem statement. Modern integration processes equalize the conditions of economic activity, eliminate national barriers for economic entities in world markets, have a positive impact on the movement of resources, including investment and openness to innovation.

The issue of foreign investment remains extremely important for Ukraine, which has long experienced an acute shortage of domestic finances for the modernization and development in sectors of the economy. After all, it is a foreign investment that makes it possible to provide the most stable competitive advantages in all spheres of economic activity, including the market environment, in an innovative way.

Analysis of recent research and publications. The theoretical basis of innovation processes and problems of their financial, information support and state regulation of innovation is extensively described in the works of prominent foreign scientists: S. Valdaytseva, G. Kovaleva, S. Rumyantseva, B. Santo, B. Twiss, A. Thompson, R. Fatkhutdinov, J. Schumpeter, Y. Yakovets; domestic scientists: A. Amosha, Y. Bazhala, V. Geets, M. Gladiya, V. Zakharchenko, I. Lukinov, S. Pokropivny, P. Cabluk, L. Fedulova, M. Chumachenko, A. Shestopal, O. Shmagliya, O. Ulyanchenko and others.

Paying tribute to the scientific developments of these authors, we should note that a systematic approach to the study of investment and innovation development of agriculture in Ukraine, as an extremely important primary sector of the economy and related industries, remains relevant and encourages us to detail certain issues, one of which is the research of practical experience of investment-innovation-oriented management and its efficiency on the example of an enterprise or industry.

The purpose of the article is to study the role of investment and innovation mechanism to overcome the crisis in the malt industry of Ukraine, generalize the world experience of efficient use of foreign capital, and reveal the features of investment and innovation activities of global malt corporations Malteurop and Soufflet. on the way to the formation of a modern raw material base for malt production in the brewing industry of Ukraine.

Presentation of the basic research material. Many qualitatively new prospects have emerged for the domestic economy with the independence of Ukraine. First of all, it has become more open to the whole world. In addition, Ukraine has always ranked second in the USSR in terms of economic and social development after Russia and it had a very favorable geographical position and a favorable climate for the promising future of the new state. 
However, economic and social instability, as the cause and effect of the long crisis, positioned it as a country in transition with all its inherent features. It soon became clear that Ukraine would not be able to overcome these problems on its own with the help of its own resources. The aim was to attract funds from outside - foreign investment. But due to a combination of many negative factors, foreign investors were not in a hurry to invest in our economy. According to statistics, the process of increasing foreign direct investment in Ukraine's economy in the dynamics of these years is not uniform: the downward trend in investment in Ukraine was overcome in 1998, the rapid growth of investment from 2005 to 2009, in particular, when their total amount increased 4 times, was gradually slowing down due to the crisis processes of $2009^{1}$. (Fig. 1)

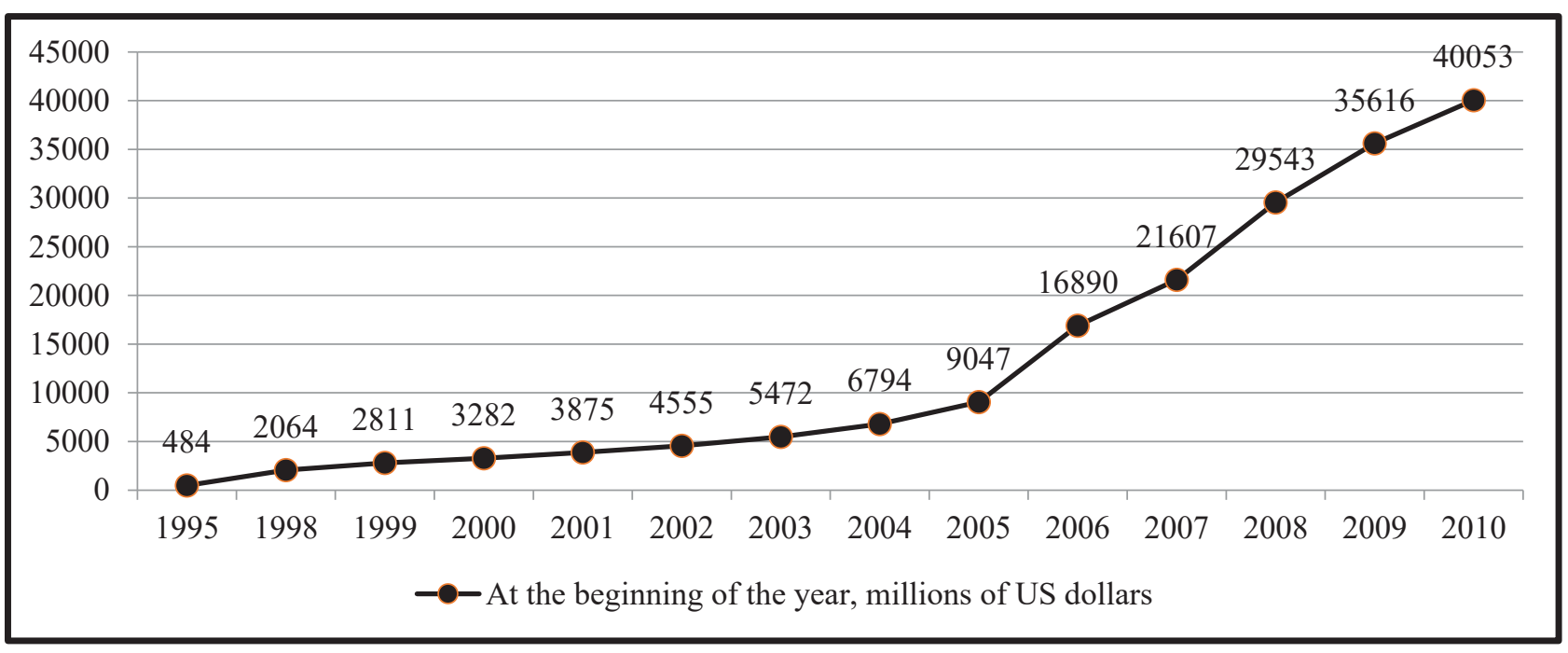

Fig. 1. Foreign direct investment in Ukraine during the formation of the malt industry According to the State Statistics Committee

The main investors in the Ukrainian economy for a decade in the ranking are Cyprus, Germany, the Netherlands, Russia, Austria, France and Great Britain; together they invest 2/3 of all funds 2 .

Traditionally, developed countries have exported and imported capital to the same extent, while developing countries have imported much more than they have exported ${ }^{3}$.

The largest volumes of investments were made in trade, in the field of food production investment flows increased almost 6 times. Significant investments are also made in agricultural processing, real estate, finance, engineering, transport and communications. Unfortunately, the volume of foreign investment in agriculture is very small (about 3\%) and is one of the lowest among all industries ${ }^{4}$.

The malt industry, which was not considered a priority in the economy, in its development could only count on the support of foreign investors, which came true in those years.

After decades of stagnation, the main cause of which was the anti-alcohol company of the $1980 \mathrm{~s}$, the Ukrainian brewing industry has gained significant revival only since 1998, reaching beer production of 70 million dollars, and in 2008 was able to quadruple it to peak volumes. 320.3 million dollars (69 liters of beer per Ukrainian). It was the most productive year for beer producers ${ }^{5},$.

\footnotetext{
${ }^{1}$ Офіційний сайт Державного комітету статистики України (2020). Головна сторінка

$<$ http://www.ukrstat.gov.ua/> (2020, July, 07).

2 Духницький, Б. В. (2011). Іноземні інвестиції в економіці України. Облік і фінанси АПК: бухгалтерський портал, 2, 89-92.

${ }^{3}$ World Investment Report (2009). Transnational Corporations, Agricultural Production and Development

$<$ http://www.unctad.org/en/docs/wir2009_en.pdf> (2020, July, 07).

4 Духницький, Б. В. (2011). Іноземні інвестиції в економіці України. Облік і фінанси АПК: бухгалтерський портал, 2, 89-92.

${ }^{5}$ Офіційний сайт Державного комітету статистики України (2020). Головна сторінка

$<$ http://www.ukrstat.gov.ua/> (2020, July, 07).

${ }^{6}$ Абраменкова А. (2014). Обзор рынка пива, 3, 40-47.
} 
However, foreign investors in the beer industry - the world's powerful breweries BBN (Baltic Beverages Holding) and Sun Interbrew (owner, after the merger in 2004 - In Bev), introducing into the production of beer in Ukraine world beverage quality standards, faced a shortage of raw ingredients for the production of beer - hops and malt, which would approximately meet the requirements of European standards.

Diagnosis of the malt industry was carried out by foreign investors - malt corporations of world importance - Malteurop and Soufflet, who intended to start their production activities in Ukraine and it gave disappointing results.

The volume of domestic malt production did not fully meet the growing needs of the brewing industry. Malt plants, which began to develop in 2000 after a period of stagnation, managed to record total production at only 15 thousand tons per month. Annual malt production in 2001-2002 amounted to 152.8 and 173.3 thousand tons or $77 \%$ of the demand of 196 and 224.7 thousand tons, respectively ${ }^{1}$.

National malt production at that time was represented by two specialized enterprises: in the city of Slavuta, Khmelnytsky region - a plant of Baltic Beverages Holding with a capacity of 80 thousand tons and a plant in Berdychiv with 50 thousand tons ${ }^{2}$ and a malting plant Sun Interbrew in Chernihiv, with a capacity of 22 thousand tons. The means and equipment of these enterprises were physically and morally worn out, energy costs remained very high, imperfect outdated technology of malt production was used. Malt at these plants with technically obsolete equipment and technology was expensive, unacceptably low quality, as a result, not competitive in the raw materials market of the brewing industry. This is what prompted the Ukrainian brewer to purchase significant amounts of uncovered shortage abroad.

However, the biggest surprise and vital problem for the malt industry, which had to work by world standards, was the lack of raw materials - barley with a quality that would satisfy the modern production of beer. Ukrainian barley, which came from the local market by selecting "the best we have", had the status of conditionally brewing, because most of its quality indicators did not even meet the requirements of State standards of Ukraine (DSTU), not to mention world standards.

Ukraine, which is famous for its chernozems and belongs to the countries of the world with favorable soil and climatic conditions for growing malting barley, received mainly feed grain with a yield of 20001.86 tons a year, $1.97 \mathrm{t} /$ ha in 2010, due to extensive farming and lack of barley varieties with stable genetically determined traits of malt quality. It is two to three times lower than European figures ${ }^{3}$.

In addition, malt enterprises did not have stable production links with the agricultural producer, but only sporadic relationships when buying barley on the domestic market.

According to research, only an investment-innovative model of forming a completely new raw material base could solve a number of these problems. It could harmoniously combine efforts, financial opportunities and partnership principles, significantly increase the efficiency of malting barley production, and the competitiveness of malt to the level of European standards ${ }^{4}$.

However, the own innovative development of malt enterprises and related agro-industrial sector was hampered by lack of necessary resources: lack of state support, lack of working capital, and sometimes lack of real understanding of the vital need and importance of innovation by existing management ${ }^{5}$.

The malt industry of brewing needed urgent radical reform and significant financial investments, so the basis of the strategy of its development by foreign investors were:

- reconstruction of existing enterprises and construction of new ones;

- creation of a modern raw material base by forming a network of partner farms that would provide malt production in the required volumes and with quality that would meet the requirements of world standards on long-term contractual terms.

\footnotetext{
${ }^{1}$ Офіційний сайт Приватного акционерного товариства "Украинська галузева компанія по виробництву пива, безалкогольних напоїв та минеральных вод “УКРПИВО”(2020). Головна сторінка <http://www.ukrpivo.com> (2020, July, 07).

2 Пивное дело (2013). Украинский солод. Международный аналитический журнал, 1

$<$ https://www.pivnoe-delo.info/ukrainskiy-rynok-soloda $>$ (2020, July, 07).

${ }^{3}$ Офіційний сайт Приватного акционерного товариства Украинська галузева компанія по виробництву пива, безалкогольних напоїв та минеральных вод УКРПИВО (2020). Головна сторінка $<$ http://www.ukrpivo.com> (2020, July, 07).

${ }^{4}$ Ibid.

${ }^{5}$ Пивное дело (2013). Украинский солод. Международный аналитический журнал, 1

$<$ https://www.pivnoe-delo.info/ukrainskiy-rynok-soloda $>$ (2020, July, 07).
} 
Prerequisites for investment in the malt industry of Ukraine were:

- favorable geopolitical location of the country: the access to the Black Sea basin; located at the crossroads of Europe - Asia, North - South;

- high level of natural resource security - the world's most fertile land and cheap skilled labor as important factors in reducing production costs and increasing its competitiveness;

- capacious consumer domestic malt market;

- the desire to gain a foothold on a long-term basis in the promising market of Ukraine;

- inter-corporate agreements of BBH, Malteurop and Soufflet with leading beer producers in Ukraine and Western, Central and Eastern Europe to provide their production with malt.

- establishment of a regime to promote investment activities at the level of regional administrative authorities.

The key source of foreign direct investment in Ukraine is private foreign investors. They do not act just as an additional investment resource, but also provide quite effective opportunities to learn the experience of management and administration and help in the development of new modern technologies.

W should say that the formation of the malt industry in Ukraine in the first decade of the new century was due to the incredible efforts of foreign investors - global corporations of French origin in the production of malt Soufflet and Malteurop. They were able to attract domestic Obolon Corporation to invest in the development of the industry, by creating a competitive environment.

To build a modern malting plant with an annual production of 100 thousand tons, depending on the project and regional conditions, according to experts, costs about $\$ 30-40$ million. These three companies, which are currently the main ones in the malt market of Ukraine, in a record short period from 2003 to 2009, investing about $\$ 200$ million in equity and borrowed from the EBRD, radically modernized the production capacity of the malt industry to European standards, developed and introduced, taking into account local conditions, innovative technologies in production.

Chronology of malt industry development in Ukraine:

1. In March 2000, the Berdychiv Malt Plant complex was bought out by Berdychiv Malt Company LLC, which gave it a second life. Using the private capital of individuals, a new team of managers in 2001 developed and implemented a targeted program to modernize obsolete production, trained the necessary staff, increased production capacity in 2002 - to almost 14 thousand tons, in 2003 - almost 27 thousand, in 2004 more 50 thousand tons of products that meet the modern requirements of the brewing industry ${ }^{1}$.

2. In June 2001, the French corporation Malteurop Group, one of the world's leading malt producers, signed an agreement with the Belgian company Sun-Interbrew to supply malt in Western, Central and Eastern Europe. Under the agreement, Interbrew sells a malting plant at the Desna plant in Chernihiv, and Malteurop is renovating it, increasing its production capacity from 22,000 tons to 55,000 tons of malt per year, and agreeing to build a 105,000-tonne malt house at Kharkiv's Rohan brewery ${ }^{2}$.

The projects were successfully implemented in 2003-2005. Both projects were financed by $53 \%$ thanks to the credit resources of the European Bank for Reconstruction and Development and by $47 \%$ by the equity of a foreign investor in the form of funds and equipment. Construction work was carried out by Ukrainian companies. The equipment installed at the plant was $80 \%$ of Ukrainian production. The peculiarity of the projects was that in addition to malt production, a program of growing malting barley was implemented ${ }^{3}, 4$.

3. In October 2004, Groupe Soufflet, having acquired a controlling stake in Slavutych Malt Plant, became its main shareholder and launched its own investment program ${ }^{5}$, , with the support of another shareholder - the European Bank for Reconstruction and Development (EBRD). Reconstruction of the malt plant, which was completed in 2008, radically modernizes production and doubles its capacity from 80

\footnotetext{
${ }^{1}$ Международный аналитический журнал Пивное дело (2013). Украинский солод, 1.

$<$ https://www.pivnoe-delo.info/ukrainskiy-rynok-soloda $>$ (2020, June, 28).

${ }^{2}$ Ibid, 10.

${ }^{3}$ Офіційний сайт Groupe Soufflet (2020). Головна сторінка $<$ http://www.soufflet-agro.com.ua/uk/suffle-agro/history/> (2020, June, 28).

${ }^{4}$ Офіційний сайт корпорації Оболонь (2020). Головна сторінка $<$ https://obolon.ua/ua/about/history?page=3> (2020, June, 28).

${ }^{5}$ Международный аналитический журнал Пивное дело (2013). Украинский солод, 1.

$<$ https://www.pivnoe-delo.info/ukrainskiy-rynok-soloda $>$ (2020, June, 28).

${ }^{6}$ Офіційний сайт Groupe Soufflet (2020). Історія <http://www.soufflet-agro.com.ua/uk/suffle-agro/history/>

(2020, June, 28).
} 
to 160 thousand tons of malt per year. In addition to malt production, the project implements a program of growing malting barley.

4. Construction of the most modern malt plant of the domestic corporation "Obolon" in Chemerivtsi, Khmelnytsky region with a capacity of 120 thousand tons ${ }^{1},{ }^{2}$ is one of the most expensive investment projects of the malt industry implemented for the period from 2005 to 2009 worth $\$ 100$ million. The world's leading companies were selected to complete the production. According to the degree of equipment and perfection of processes, the malt plant has reached the European level. The enterprise is certified on 4 ISO systems.

The modern malt industry of Ukraine is a number of modernized and newly built enterprises with a total capacity of 535 thousand tons with an estimated need of 360 thousand tons ${ }^{3},{ }^{4}$. They have the highest level of automation of all production processes, computerized control of technology and quality management, implemented and certified integrated management systems according to international standards, which ensure the company's responsibility to staff, consumers, society and the state and allow the sale of malt in the market of WTO members.

In the agricultural sector, the basis of the process of forming the raw material base of the brewing industry were initiated by malting corporations on the basis of investment agricultural program of innovative development of barley production and implementation of brewing quality management system, which included:

- research and identification of favorable regions for growing malting barley;

- determining the degree of brewing suitability of barley varieties of Ukrainian selection according to the methods of European standards;

- study of the possibility of adaptation of varieties of foreign selection to the soil - climatic conditions of Ukraine while maintaining stable selection conditions for brewing quality 5 .

- introduction into production of new high-yielding grades and innovative technologies;

- annual supply at discounted prices of high-quality seeds, monitoring the need for fertilizers, trace elements, growth stimulants and plant protection products;

- consulting support for barley production with mandatory provision of recommendations on the specific application of elements of technology;

- creating a climate to promote efficient production of malting barley through the formation of forward and futures contractual relationships;

- alignment of the methodology for determining the quality of brewing in Ukraine to European standards.

The success of investment and innovation orientation of these programs is characterized by a dynamic increase in barley yields in farms operating under partnership agreements with malt corporations from 1.7 $\mathrm{t} / \mathrm{ha}$ in 2003 to $5.0 \mathrm{t} / \mathrm{ha}$ in 2019 , against the national average, respectively $1,5 \mathrm{t} / \mathrm{ha}$ and $3.5 \mathrm{t} / \mathrm{ha}^{6}$. The innovative model of malting barley production provides the domestic malting industry in full demand with its own raw materials at the level of European standards and is able to significantly increase its supply to foreign markets.

The mutually beneficial partnership of international malting corporations and farmers helps them to make barley crops highly profitable and competitive, diversify the barley market and provide an impetus for the fuller disclosure of its export potential, make barley growing profitable and attractive in the long run.

Conclusions. The set of investment and innovation measures implemented by foreign investors global malt corporations is designed to harmoniously combine related malt and agricultural industries to achieve a consolidated result and get competitive quality products that have a guaranteed and stable market.

\footnotetext{
${ }^{1}$ Международный аналитический журнал Пивное дело (2013). Украинский солод, 1.

$<$ https://www.pivnoe-delo.info/ukrainskiy-rynok-soloda $>$ (2020, June, 28).

${ }^{2}$ Офіційний сайт корпорації Оболонь (2020). Головна сторінка $<$ https://obolon.ua/ua/about/history?page=3> (2020, June, 28).

${ }^{3}$ Офіційний сайт Приватного акционерного товариства Украинська галузева компанія по виробництву пива, безалкогольних напоїв та минеральных вод УКРПИВО (2020). Головна сторінка <http://www.ukrpivo.com> (2020, July, 07).

${ }^{4}$ Сташейко, В. І. (2013). Розвиток сировинної бази пивоваріння в Україні. Економіка АПК, 9, 25-31.

$<$ http://nbuv.gov.ua/UJRN/E_apk_2013_9_6> (2020, June, 28).

${ }_{5}^{5}$ Офіційний сайт Державного комітету статистики України (2020). Головна строінка

$<$ http://www.ukrstat.gov.ua/> (2020, June, 28).

${ }^{6}$ Ibid.
} 
Efficient barley production embodies high yields and quality, contributes to the diversification of the barley market and provides an impetus for fuller disclosure of its export potential.

Long-term and quite effective results of the partnership of malting corporations and agricultural producers confirm that the established business relations are harmonious and rationally combined with the aspirations of the parties.

Proper understanding of the motives and interests of foreign investors and a system of regulation capable of combining the interests of foreign investors with the national economic interests of the state can expand our country's ability to attract foreign capital.

It is wrong to focus only on foreign sources of investment as a basis for the progressive development of our state's economy, because at the same time, there is a negative impact of transnational corporations on the domestic economy. The national industries they invest in still often become completely financially dependent on the strategy of their activities, the management of TNCs from abroad and the dictates of the rules of the market do not always coincide with national interests.

Today, the malt industry, copying the dynamics of brewing is in a stage of a temporary decline in production, but the production capacity of upgraded to world-class enterprises, ready to withstand any test and load, in accordance with the capacity of domestic and foreign markets.

\section{References:}

1. Oficijnyj sajt Derzhavnoho komitetu statystyky Ukrayiny (2020) [Official site of the State Statistics Committee of Ukraine (2020)]. Holovna storinka [Homepage] <http://www.ukrstat.gov.ua/> (2020, June, 28). [in Ukrainian].

2. Dukhnytskyi, B. V. (2011). Inozemni investycii v ekonomitsi Ukrayiny [Foreign investment in the economy of Ukraine]. Oblik i finansy APK: bukhgalterskyj portal [Accounting and finance of agro-industrial complex: accounting portal], 2. [in Ukrainian].

3. World Investment Report (2009). Transnational Corporations, Agricultural Production and Development. $<$ http://www.unctad.org/en/docs/wir2009_en.pdf> (2020, June, 28). [in English].

4. Oficijnyj sajt Pryvatnoho akcionernoho tovarystva Ukrayinska haluzeva kompaniya po vyrobnycztvu pyva, bezalkoholnykh napoyiv ta mineralnykh vod UKRPYVO (2020) [Private joint-stock company Ukrainian branch company for the production of beer, soft drinks and mineral waters UKRPIVO (2020)]. Holovna storinka [Homepage] <http://www.ukrpivo.com> (2020, June, 28). [in Ukrainian].

5. Mezhdunarodnij analytycheskyj zhurnal Pyvnoe delo (2013). [International analytical journal Beer case (2020)] Ukraynskyj solod [Ukrainian malt], 1. <https://www.pinnoe-delo.info/ukrainskiy-rynok-soloda> (2020, June, 28). [in Ukrainian].

6. Abramenkova, A. (2014). Obzor rinka pyva [Beer market overview], 3, 40-47.[in Russian].

7. Stashejko, V. I. (2013). Rozvytok syrovynnoyi bazy pyvovarinnya v Ukrayini [Development of raw material base of brewing in Ukraine]. Ekonomika APK [Economics of agro-industrial complex], 9, 25-31. $<$ http://nbuv.gov.ua/UJRN/E_apk_2013_9_6> (2020, June, 28). [in Ukrainian].

8. Shmaglij, O. B. (2014). Rozvytok innovacijnoyi infrastruktury pyvovarinnya Ukrayiny [Development of innovative brewing infrastructure of Ukraine]. Prodovolchi resursy [Food resources], 2, 112-119. $<$ http://nbuv.gov.ua/UJRN/pr_2014_2_24> (2020, June, 28). [in Ukrainian].

9. Oficijnyj sajt Groupe Soufflet (2020) [Groupe Soufflet (2020)]. Istoria [History] $<$ http://www.soufflet-agro.com.ua/uk/suffle-agro/history/> (2020, June, 28). [in Ukrainian].

10. Oficijnyj sajt Malteurop Groupe Vivescia (2020).[Official web-site the Malteurop Groupe Vivescia (2020)]. Holovna storinka [Homepage] <https://www.malteurop.com/en/our-history> (2020, June, 28). [in Ukrainian].

11. Ofitsinyi sait korporatsii Obolon (2020).[Official web-site the Obolon corporation (2020)]. Holovna storinka [Homepage] $<$ https://obolon.ua/ua/about/history?page=3> (2020, June, 28). [in Ukrainian]. 